\title{
Technical Efficiency and the Determinants of Price to Book Value: An Empirical Study of Category-IV Banks in Indonesia Stock Exchange
}

\author{
Dr. Drs. Chandra Setiawan, M.M., Ph.D*), \\ Management Study Program, Faculty of Business, \\ President University, Indonesia. \\ E-mail: chandra@president.ac.id \\ Felicia Putri Tjiasaka, \\ Management Study Program, Faculty of Business, \\ President University, Indonesia. \\ E-mail: feliciaputritjiasaka@gmail.com
}

\begin{abstract}
This research aimed to empirically determine the value relevance of price to book value (PBV) and technical efficiency (TE) within Category-IV banks in Indonesia Stock Exchange in the time horizon of 1Q2007 to 4Q2015. This research uses time series and quarterlypublished financial statement from the listed Category-IV banks. In term of variables that determine PBV by using panel least square, the research reveals that pre-provision operating profit (PPOP) and return on total assets (ROTA) have positive and significant effect towards PBV, while non-performing loan (NPL) and dividend yield have negative and significant effect towards PBV. Contrarily, firm size has negative and insignificant effect towards PBV. Additionally, the result of data envelopment analysis (DEA) which is used to measure technical efficiency, indicates that PT. Bank Mandiri Tbk. (BMRI) is the most efficient Category-IV bank. BMRI led with average technical efficiency score of $98.95 \%$, followed by PT. Bank Rakyat Indonesia Tbk. (BBRI) 98.02\%, PT. Bank Negara Indonesia Tbk. (BBNI) 96.04\% and PT. Bank Central Asia Tbk. 94.94\%. The average technical efficiency of Category-IV banks within the period of research is $96.99 \%$.
\end{abstract}

Keywords: Price to Book Value, Technical Efficiency, Data Envelopment Analysis

\section{Introduction}

Banking has been playing a crucial role in accelerating a country's economy. To a lesser extent, banks are responsible in allocating assets and providing liquidity transformation within the economy (Lee, Park, et al., 2013). Every business sector and layer of population are linked to bank, either by the spurred lending opportunity, the accessibility to worldwide payment system, the value added assets in bank's deepening products, or the financial inclusion agents amongst the rural.

With the growth of financial market, bank stocks explain a substantial portion of the total market capitalization. Bank stocks make up about one-tenth of the total market capitalization in both emerging and developed countries (Yang \& Tsatsaronis, 2012). In Indonesia Stock Exchange (IDX), four big banks' stocks (BBRI, BMRI, BBCA, BBNI) contribute $17.56 \%$ in forming Jakarta Composite Index (JCI). In a greater mean, banking sector stocks contribute $30.99 \%$ in total market capitalization. 
Table 1.1 Market Capitalization by Sector and Top-10 Weighted Stocks

\begin{tabular}{|c|l|c|}
\hline No. & Sector & Weight (\%) \\
\hline 1. & Financials & $\mathbf{3 0 . 9 9 \%}$ \\
\hline 2. & Consumer Staples & $26.89 \%$ \\
\hline 3. & Consumer Discretionary & $12.03 \%$ \\
\hline 4. & Telecommunication Services & $10.28 \%$ \\
\hline 5. & Materials & $5.67 \%$ \\
\hline 6. & Industrials & $4.50 \%$ \\
\hline 7. & Energy & $4.05 \%$ \\
\hline 8. & Health Care & $3.22 \%$ \\
\hline 9. & Utilities & $1.42 \%$ \\
\hline 10. & Others & $0.95 \%$ \\
\hline
\end{tabular}

\begin{tabular}{|c|l|c|}
\hline No. & \multicolumn{1}{l|}{ Stock Ticker } & Weight $(\%)$ \\
\hline 1. & HMSP & $8.27 \%$ \\
\hline 2. & TLKM & $7.24 \%$ \\
\hline $\mathbf{3 .}$ & BBCA & $\mathbf{6 . 3 6 \%}$ \\
\hline 4. & UNVR & $6.01 \%$ \\
\hline 5. & ASII & $5.67 \%$ \\
\hline $\mathbf{6 .}$ & BBRI & $\mathbf{4 . 8 7 \%}$ \\
\hline $\mathbf{7 .}$ & BMRI & $\mathbf{4 . 4 8 \%}$ \\
\hline 8. & GGRM & $2.16 \%$ \\
\hline 9. & ICBP & $1.92 \%$ \\
\hline $\mathbf{1 0 .}$ & BBNI & $\mathbf{1 . 8 5 \%}$ \\
\hline
\end{tabular}

Source: Bloomberg, 30 November 2016

Table 1.2 Category-IV Banks Contribution to Commercial Banks Assets

\begin{tabular}{|l|c|c|c|c|}
\hline & $\mathbf{2 0 1 2}$ & $\mathbf{2 0 1 3}$ & $\mathbf{2 0 1 4}$ & $\mathbf{2 0 1 5}$ \\
\hline Commercial Banks Assets (Rp bn) & 4,262 & 4,954 & 5,615 & 6,132 \\
\hline Category-IV Banks Assets (Rp bn) & 1,962 & 2,241 & 2,477 & 2,728 \\
\hline Category-IV to Commercial Banks Assets & $46 \%$ & $45 \%$ & $44 \%$ & $44 \%$ \\
\hline
\end{tabular}

Source: Indonesian Banking Statistics, 2015

Besides their significant contribution to total market capitalization, these 4 banks classified in Category-IV also dominate up to $40 \%$ of total market share represented by total assets. Per reported December 2015, 4 out of 118 banks in Indonesia control almost half of the banking sector activities. The market share of these four banks simply shows the significance towards Indonesian banking industry.

Due to bank's high significance towards the economy and the capital market index, studying the determinants of banks valuation and stock returns have caught the interest of global fund managers and investors. Many empirical studies have examined the bank stock returns, as it stands as the best proxy for bank performance.

Eugene Fama (1991) explained three forms of economy in Efficient Market Hypothesis $(\mathrm{EMH})$ theory. In strong form, the stock price reflects the real value of the stock's performance, while vice versa applies to weak form economy. Indonesia is categorized as weak form market (Utami, 2013), which drives the researcher to study the valuation instead of stock price, for examining the real performance of banking.

Moreover, the researcher tries to examine the alteration of competition landscape within the big banks in Indonesia, in which ASEAN Economic Community has attracted new players from global banking system. Initially, banks from more developed countries tend to have better resource management due to their scale of efficiency (Utami, 2013). Similarly, per quoted local newspaper (Bisnis Indonesia, 2016), Muliaman Hadad, Chief of Financial Service Authority (OJK) of Indonesia, once explained in February 2016, that he aimed to cap the net interest margin (NIM) of bank. This is due to resource management inefficiency compared to national banks in ASEAN countries. Category-IV banks in Indonesia can generate NIM at c.7-8\%, whilst Thailand banks are generating c.3-4\%, 
implying room to cut margin for accelerating credit growth. Therefore, the researcher adds technical efficiency analysis in the study, to see whether there is adjustment prior to the establishment of ASEAN Economic Community 2015.

Adams and Rudolf (2010) as per quoted in Oleg (2011), distinguished the characteristics of banking business into four characteristics, motivating a distinct valuation approach. First, banking is a heavily regulated industry. Second, banks operate on both sides of their balance sheets, actively seeking profits not only in lending but also in raising capital. Third, banks are exposed to credit default risk, but they also actively seek risk as part of their business model. Fourth, the profit and value of a bank are much more dependent on interest rate than other industries.

Referring to the aforementioned banking characteristics, the researcher combines both asset-based and income-based approach as banks' microeconomics drivers. In a bank's balance sheet, asset is mostly contributed by loans. Thus, to measure asset quality, the Non-Performing Loan (NPL) ratio is believed as the best proxy (IMF, 2016).

In income-based approach, the goal is to value the profitability of a bank, which is often proxied by Return on Equity (ROE). Lee, Park et al. (2013) suggest in their scientific findings, that the key driver in measuring profitability is growth in Pre-Provision Operating Profit (PPOP) and Return on Assets (ROA). PPOP is a measure of the revenue growth and management ability to control operating costs.

To complete the relevancy of study, dividend yield and firm size (Marangu \& Jagongo, 2014) are added as the determinants for measuring resource management and yield towards market price. Therefore, this study aims to analyze the determinants of Indonesia banking stock valuation, represented by Price-to-Book Value (PBV).

Besides determining value relevance of PBV, Rahmawati (2015) found that commercial banks in Indonesia could not maintain technical efficiency persistently. According to her, the average technical efficiency of commercial banks in Indonesia period March 2010 - December 2013 with Data Envelopment Analysis (DEA) method was $93.25 \%$, implying the inefficiency within the unit analysis. Due to this result, the researcher is given reason to test out the efficiency in Category-IV banks only, with longer time horizon from 1Q2007 to 4Q2015.

This paper is structured with Section 1 discussing on the research background, followed by Section 2 reviewing the theoretical literature, Section 3 elaborating the research methodology, Section 4 explaining the empirical results, and Section 5 for conclusion and recommendation.

\section{Literature Review}

\subsection{Value Relevance of Price to Book Ratio}

The primary role of the capital market is allocation of ownership of the economy's capital stock. In general terms, the ideal is a market in which prices provide accurate signals for resource allocation: that is, a market in which firms can make productioninvestment decisions, and investors can choose among the securities prices at any time that 
"fully reflect" all available information. A market in which prices always "fully reflect" available information is called "efficient" (Fama, 2000).

Inside the journal, Fama (2000) elaborated the theory into empirical work concerned with the adjustment of security prices to three relevant information subsets. First, weak form, where the information set is just historical prices. Second, semi-strong form, where the concern is whether prices efficiently adjust to other information that is obviously publicly available (e.g., announcements of annual earnings, stock splits, etc.). Third, strong form, concerned with whether given investors or groups have monopolistic access to any information relevant for price formation.

Under this Sharpe [40] - Lintner [24, 25] modified parameter, Indonesia is categorized into weak strong form of market efficiency. Stock price is less accurate to reflect the real company / industry performance in the semi-strong and weak form countries. Therefore, instead of market value, analysts and investors are suggested to study book value to measure the real performance.

Banking industry is rated as one of the most difficult sector to be valued, due to its huge differences in term of financial statement and business operation compared to other industries. Damodaran (2002) stated two practical problems in valuing banks; first, the estimation of cash flows could not be performed without estimating reinvestments; second is that estimating expected future growth becomes more difficult if the reinvestment rate cannot be measured.

Price to book value (PBV) is the most frequent screening utilized by investment community to pinpoint selected securities in the portfolio management. PBV valuation provides the final and perhaps the most thorough assessment by the capital market of a company's overall status (Walsh, 1996). Consequently, it helps investors to capture the summary of company's profitability, liquidity, management performance and future chances (Reilly \& Brown, 1997). The low PBV is attractive for portfolio manager, as it is generally considered as undervalued and expected to outperform those with high PBV. Nevertheless, most people only know how to calculate PBV ratio, and often lack of insights on what factors driving the ratio (Raymond, 2013).

Many financial accountants and analysts still believe that return on equity (ROE) is the most appropriate measure of financial performance, as it reflects bank's profitability. However, Lee, Park, et al. (2013) proved ROE to be less accurate, by comparing the median annual share price returns of global emerging markets (GEM) and developed markets (DM) banks and perform panel data regression to corroborate the findings. They suggest to look at PPOP growth, due to these reasons: 1) PPOP is a more sustainable part of the $\mathrm{P} \& \mathrm{~L}$, as it is usually driven by loan growth, which is the result of economic growth and demand for credit, 2) PPOP is generated by the top part of the P\&L, indicating that a stronger growth in these items would translate to greater net profit growth as a result of operating and financial leverage, 3) PPOP growth is usually driven by loan growth and asset increase, which helps support higher leverage ratio (asset/equity) and in turn, higher levels of ROE. 
Marangu \& Jagongo (2014) found that there was a statistically significant relationship between price to book value and return on total assets (ROTA), return on equity (ROE) and dividend yield at the Nairobi Stock Exchange (NSE), Kenya. In addition, there was no statistically relationship between price to book value ratio and dividend payout ratio and growth rate in earnings after tax. Similarly, Constantinidis (2008) found the positive relationship between PBV and size and profitability, in which smaller capitalization banks are notched with lower PBV, and vice versa.

Table 2.1 Previous Research of PBV Value Relevance

\begin{tabular}{|c|c|c|c|c|c|}
\hline \multirow{2}{*}{$\begin{array}{l}\mathbf{N} \\
\mathbf{0}\end{array}$} & \multirow{2}{*}{$\begin{array}{l}\text { Author/ } \\
\text { Year }\end{array}$} & \multirow{2}{*}{ Title } & \multicolumn{2}{|c|}{ Variables } & \multirow{2}{*}{ Research Design } \\
\hline & & & Independent & Dependent & \\
\hline 1 & $\begin{array}{c}\text { Hidayah/ } \\
2014\end{array}$ & $\begin{array}{l}\text { The Effect } \\
\text { of Firm } \\
\text { Characterist } \\
\text { ic Toward } \\
\text { Firm Value } \\
\text { in the } \\
\text { Property } \\
\text { and Real } \\
\text { Estate Firm } \\
\text { in Indonesia } \\
\text { Stock } \\
\text { Exchange } \\
\end{array}$ & $\begin{array}{l}\text { a. Managerial } \\
\text { ownership } \\
\text { b. Debt to } \\
\text { equity ratio } \\
\text { c. Firm size } \\
\text { d. Return on } \\
\text { asset }\end{array}$ & $\begin{array}{l}\text { Price to book } \\
\text { value }(\mathrm{PBV})\end{array}$ & \begin{tabular}{|ll} 
a. & Population: \\
& property and real \\
& estate firms in \\
& Indonesia Stock \\
& Exchange \\
b. & Sample size: 30 \\
& property and real \\
& estate firms \\
c. & Instrument: data \\
& collection \\
d. & Data analysis: \\
& multiple regression \\
\end{tabular} \\
\hline 2 & $\begin{array}{c}\text { Marangu } \\
\& \\
\text { Jagongo / } \\
2014\end{array}$ & $\begin{array}{c}\text { Price to } \\
\text { Book Value } \\
\text { Ratio and } \\
\text { Financial } \\
\text { Statement } \\
\text { Variables } \\
\text { (An } \\
\text { Empirical } \\
\text { Study of } \\
\text { Companies } \\
\text { Quoted at } \\
\text { Nairobi } \\
\text { Securities } \\
\text { Exchange, } \\
\text { Kenya) }\end{array}$ & $\begin{array}{l}\text { a. Dividend } \\
\text { payout ratio } \\
\text { b. Return on } \\
\text { assets } \\
\text { c. Return on } \\
\text { equity } \\
\text { d. Return per } \\
\text { share } \\
\text { e. Dividend } \\
\text { yield } \\
\text { f. Earnings } \\
\text { growth after } \\
\text { tax }\end{array}$ & $\begin{array}{c}\text { Price to } \\
\text { book value } \\
\text { (PBV) }\end{array}$ & \begin{tabular}{|l} 
a. Population: listed \\
companies in \\
Nairobi Securities \\
Exchange \\
b. Sample size: 20 \\
companies in \\
NSE20 index \\
c. Instrument: data \\
collection \\
d. Data analys is: \\
multiple regression
\end{tabular} \\
\hline 3 & $\begin{array}{l}\text { Lee, } \\
\text { Park, } \\
\text { et.al / } \\
2013\end{array}$ & $\begin{array}{c}\text { What is the } \\
\text { Key Driver } \\
\text { of Bank } \\
\text { Stock } \\
\text { Returns? }\end{array}$ & 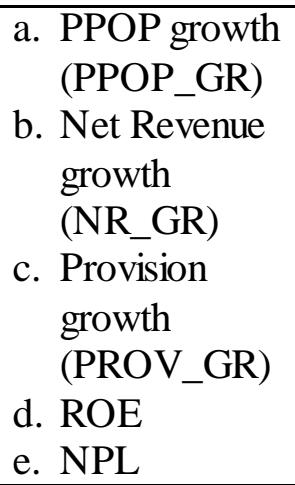 & $\begin{array}{c}\text { Price to } \\
\text { Book Value } \\
\text { (PBV) }\end{array}$ & $\begin{array}{l}\text { a. Population: Global } \\
\text { banks classified in } \\
\text { MSCI } \\
\text { b. Sample size: } 228 \\
\text { banks } \\
\text { c. Instrument: data } \\
\text { collection } \\
\text { d. Data analysis: } \\
\text { multiple regression }\end{array}$ \\
\hline
\end{tabular}




\begin{tabular}{|c|c|c|c|c|c|}
\hline 4 & $\begin{array}{c}\text { Nasehah } \\
\quad \& \\
\text { Widyarti } \\
\text { / } 2012\end{array}$ & $\begin{array}{c}\text { Analisis } \\
\text { Pengaruh } \\
\text { ROE, DER, } \\
\text { DPR, } \\
\text { Growth and } \\
\text { Firm Size } \\
\text { Terhadap } \\
\text { Price to } \\
\text { Book Value } \\
\text { (Studi } \\
\text { Kasus pada } \\
\text { Perusahaan } \\
\text { Manufaktur } \\
\text { yang Listed } \\
\text { di BEI } \\
\text { Periode } \\
\text { Tahun 2007 } \\
\text { - 2010) }\end{array}$ & $\begin{array}{l}\text { a. Return on } \\
\text { equity } \\
\text { b. Debt to } \\
\text { equity ratio } \\
\text { c. Dividend } \\
\text { payout ratio } \\
\text { d. Growth } \\
\text { e. Firm size }\end{array}$ & $\begin{array}{c}\text { Price to } \\
\text { book value } \\
(\mathrm{PBV})\end{array}$ & 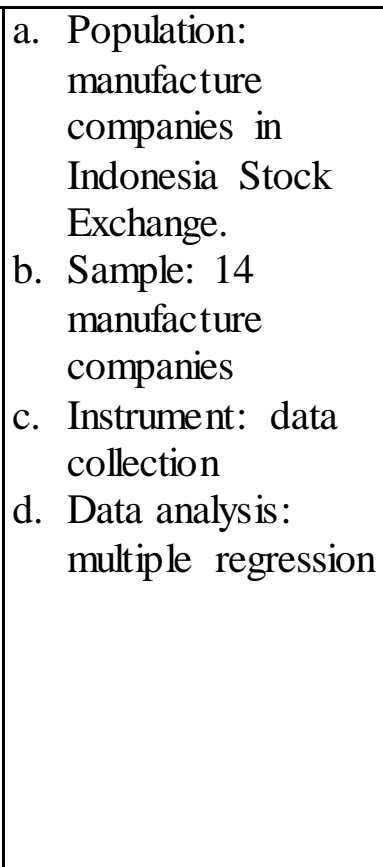 \\
\hline 5 & $\begin{array}{c}\text { Jantana / } \\
2012\end{array}$ & $\begin{array}{l}\text { Pengaruh } \\
\text { Struktur } \\
\text { Modal, } \\
\text { Profitabilita } \\
\text { s, dan } \\
\text { Likuiditas } \\
\text { terhadap } \\
\text { Nilai } \\
\text { Perusahaan } \\
\text { pada } \\
\text { Perusahaan } \\
\text { Sektor } \\
\text { Barang } \\
\text { Konsumsi } \\
\text { di BEI } \\
\text { Tahun 2007 } \\
\text { - 2011 }\end{array}$ & $\begin{array}{l}\text { a. Debt to } \\
\text { equity ratio } \\
\text { b. Return on } \\
\text { equity } \\
\text { c. Current ratio }\end{array}$ & $\begin{array}{l}\text { Value of the } \\
\text { firm (PBV) }\end{array}$ & $\begin{aligned} & \text { a. } \text { Population: } \\
& \text { consumer } \\
& \text { companies in } \\
& \text { Indonesia Stock } \\
& \text { Exchange } \\
& \text { b. Sample: } 4 \text { tobacco } \text { companies } \\
& \text { c. Instrument: data } \\
& \text { collection } \\
& \text { d. Data analys is: } \\
& \text { multiple regression }\end{aligned}$ \\
\hline
\end{tabular}

Source: Adjusted by Researchers, 2016

\subsection{Bank Efficiency and Data Envelopment Analysis}

In economic activity, efficiency concept refers to the creation of products and services with the lowest cost that can be achieved, as well as the ability to allocate economic resource for valuable usage (Taswan, 2006). Based on economic theory, there are two types of efficiency that are technical efficiency and economic efficiency. Technical efficiency has microeconomic point of view; meanwhile economic efficiency is macroeconomic. Technical efficiency tends to be limited on the technical relationship as well as operations in the conversion process of input to output. Meanwhile, in economic efficiency, the price is not assumed to be given because price can be influenced by macroeconomic policy. 
Farrel (1957) was the first to measure the efficiency empirically. According to Farrel, the concept of overall efficiency of the firm is equal to the product of the technical efficiency and price efficiency. Berger and Mester (1997) employs economic efficiency concepts- cost, revenue and standard profit, and alternative profit efficiencies. According to the both authors, the three concepts of efficiency are the most important economic efficiency concepts. These concepts have the best economic foundation for analyzing the efficiency of the financial institution.

Based on Coelli et al. (1998) and Thanassoulis (2001) cited by Bader, Mohamad, Ariff, \& Hassan (2008), cost efficiency gives a measure of how close a bank's cost is to what a best-practice bank's cost would be for producing the same bundle of output under the same conditions. Revenue efficiency indicates how well a bank is predicted to perform in terms of profit relative to other banks in the same period for producing the same set of outputs. Profit Efficiency indicates how well a bank is predicted to perform in terms of profit relative to other banks in the same period for producing the same set of outputs. This research will measure Category-IV banks technical efficiency through data envelopment analysis.

Technical efficiency (TE) is defined as the effectiveness of the given inputs to produce a certain level of outputs, which further decomposed into pure technical and scale efficiency to determine the sources of inefficiency. Usman et al. (2010) employed Data Envelopment Analysis to a panel of commercial banks operating in Pakistan for a period of 2001 - 2008 to measure the technical efficiency within, and finally found that foreign owned banks to be the most efficient and domestic private banks to be the least efficient. Chan (2011) also run similar research to commercial banks in China within $2001-2007$ by employing Data Envelopment Analysis. Results found that commercial banks in China are relatively inefficient on average.

Whilst in Indonesia, there are several researchers that have done extensive analysis on Indonesian banking system efficiency using the same DEA model. Hadad et al. (2003), Hadad et al. (2008), Putri \& Lukviarman (2008), Suseno (2008) and Suzuki \& Sastrosuwito (2011) are some of them, mostly measuring efficiency within 1998 crisis and the merger \& acquisition effect towards bank performance. The most recent research using DEA was conducted by Suzuki \& Sastrosuwito (2011) in which the samples were grouped into four groups based on ownership (government owned, privately owned, joint venture and foreign-owned). Suzuki confirmed that from 1994 to 2008, the efficiency of the Indonesian banking sector was relatively low, with the mean of overall industry being 0.866. Later he explained that productivity of the Indonesian commercial banks during the mentioned period was due to technological change than technical efficiency change.

Data Envelopment Analysis formulates the frontier of the observed input-output ratios by linear programming techniques (Fare, Grosskopf, and Lovell, 1985). DEA analysis has been used by several previous studies that involve efficient frontier estimation. Efficiency score for each unit is relative to the efficiency level of the other units in the sample. Each unit in the sample has the efficiency level that is not negative, and values between 0 and 1 , where 1 indicates perfect efficiency. There are two models that can be used to measure the efficiency, which are CRS (Constant Return to Scale) and VRS (Variable Return to Scale). 
This research will use CRS model. CRS model assumed if a bank has a ratio close to 1 , the bank is efficient, vice versa, if a bank has a ratio close to 0 , the bank is inefficient.

Table 2.2 Previous Research of Bank Efficiency

\begin{tabular}{|c|c|c|c|c|}
\hline $\begin{array}{l}\mathbf{N} \\
\mathbf{0}\end{array}$ & $\begin{array}{l}\text { Author/ } \\
\text { Year }\end{array}$ & Title & Methodology & Result and Conclusion \\
\hline 1 & $\begin{array}{l}\text { Berger; } \\
\text { De } \\
\text { Young/ } \\
1997\end{array}$ & $\begin{array}{l}\text { Problem } \\
\text { Loans and } \\
\text { Cost } \\
\text { Efficiency } \\
\quad \text { in } \\
\text { Commerci } \\
\text { al Banks }\end{array}$ & Granger Causality & $\begin{array}{l}\text { The data provide support for the bad } \\
\text { luck hypothesis - increases in } \\
\text { nonperforming loan tend to be } \\
\text { followed by decreases in measured } \\
\text { cost efficiency first introduced the } \\
\text { term Data Envelopment Analysis } \\
\text { (DEA) to measure the efficiency of } \\
\text { each Decision-Making Units (DMUs) }\end{array}$ \\
\hline 2 & $\begin{array}{l}\text { Karim et } \\
\text { al / } 2010\end{array}$ & $\begin{array}{l}\text { Bank } \\
\text { Efficiency } \\
\text { and Non- } \\
\text { Performin } \\
\text { g Loans: } \\
\text { Evidence } \\
\text { from } \\
\text { Malaysia } \\
\text { and } \\
\text { Singapore }\end{array}$ & $\begin{array}{l}\text { a. Stochastic cost } \\
\text { frontier } \\
\text { function } \\
\text { b. Tobit } \\
\text { simultaneous } \\
\text { equation }\end{array}$ & $\begin{array}{l}\text { Higher Non-Performing Loan reduces } \\
\text { cost efficiency. Likewise, lower cost } \\
\text { efficiency increases Non-Performing } \\
\text { Loan. }\end{array}$ \\
\hline 3 & $\begin{array}{c}\text { Akkaya / } \\
2013\end{array}$ & $\begin{array}{c}\text { Cost } \\
\text { Efficiency } \\
\text { Analysis } \\
\text { of } \\
\text { Swedish } \\
\text { Financial } \\
\text { Enterprise } \\
\text { s: An } \\
\text { Empirical } \\
\text { Investigati } \\
\text { on }\end{array}$ & $\begin{array}{l}\text { Stochastic cost } \\
\text { frontier function }\end{array}$ & $\begin{array}{l}\text { The estimates for the stochastic cost } \\
\text { inefficiency shows the other mortgage } \\
\text { institutions are the most efficient, } \\
\text { followed by credit market companies, } \\
\text { banking enterprises, housing credit } \\
\text { institutions and credit market entities. } \\
\text { Accordingly, mortgage institutions } \\
\text { has stronger structure than banks and } \\
\text { financial companies. }\end{array}$ \\
\hline 4 & $\begin{array}{l}\text { Soetanto } \\
\text { \& Ricky / } \\
2011\end{array}$ & $\begin{array}{c}\text { Technical } \\
\text { Efficiency } \\
\text { of } \\
\text { Indonesian } \\
\text { Commerci } \\
\text { al Banks: } \\
\text { An } \\
\text { Applicatio } \\
\text { n of Two- } \\
\text { Stage } \\
\text { DEA }\end{array}$ & $\begin{array}{l}\text { Stochastic Frontier } \\
\text { Analysis (SFA), } \\
\text { Distribution Free } \\
\text { Approach (DFA), } \\
\text { Data Envelopment } \\
\text { Analysis (DEA) }\end{array}$ & $\begin{array}{l}\text { The results indicate that the average } \\
\text { TE obtained by intermediation } \\
\text { approach shows overall mean over the } \\
\text { entire period equal to } 0.895 \text { which } \\
\text { indicates that banks could have saved } \\
10.5 \% \text { of inputs in order to produce } \\
\text { the same level of output. }\end{array}$ \\
\hline 5 & Suzuki \& & Efficiency & a. Data & The study finds that the efficiency of \\
\hline
\end{tabular}




\begin{tabular}{|c|c|c|l|}
\hline $\begin{array}{c}\text { Sastrosu } \\
\text { wito / } \\
2011\end{array}$ & $\begin{array}{c}\text { and } \\
\text { Productivi } \\
\text { ty Change } \\
\text { of the } \\
\text { Indonesian } \\
\text { Commerci } \\
\text { al Banks }\end{array}$ & $\begin{array}{l}\text { Envelopment } \\
\text { Analys is } \\
\text { (DEA) } \\
\text { Malmquist } \\
\text { Productivity } \\
\text { Index }\end{array}$ & $\begin{array}{l}\text { the Indonesian banking sector during } \\
\text { the period of 1994-2008 was } \\
\text { relatively high, with the mean of } \\
\text { overall industry being 0.866. The } \\
\text { most efficient bank group during the } \\
\text { covered period was government } \\
\text { owned, followed by joint venture and } \\
\text { foreign owned; while local } \\
\text { government owned and private owned } \\
\text { were the least efficient banks. }\end{array}$ \\
\hline
\end{tabular}

Source: Adjusted by Researcher, 2016

\subsection{Research Gap}

In recent years, there has been increased focus in the relationships of bank stock price with its financial performance and efficiency. Prior studies have generally found a positive relationship between return on equity towards price to book value (Marangu \& Jagongo, 2014; Nasehah \& Widyarti, 2012; Jantana; 2012). However, there is also study who found pre-provision operating profit as better ratio compared to return on equity (Lee, Park et al., 2013). Furthermore, many studies on Indonesia banks are conducted in short time horizon, which do not capture most of the economic phenomenon. That said, the researcher is motivated to run the study with longer horizon, more variables and adding technical efficiency analysis to fill in the gap of prior studies.

\section{Methodology}

To reach its objective, the researcher decides to use quantitative approach, which requires enumeration of the data and to use statistical analysis (Malhotra \& Birks, 2006). Secondary data is the main data collection optimized in this research, as it is considered as the most suitable approach. Secondary data is data collected by someone and being used by other person for certain purpose (Maholtra, 2010). The researcher obtains the respective data mostly from Indonesia Stock Exchange portals and public sources. To a lesser extent, the audited annual reports of 4 Category-IV banks: PT. Bank Negara Indonesia Tbk. (BBNI), PT. Bank Central Asia Tbk. (BBCA), PT. Bank Mandiri Tbk. (BMRI), and PT. Bank Rakyat Indonesia Tbk. (BBRI) from 2007 - 2015 are the primary data sources.

\subsection{Research Questions}

3.1.1. Is there any partial significant influence of pre-provision operating profit, nonperforming loan, return on total assets, dividend yield, and firm size towards price to book value in Indonesia Category-IV banks?

3.1.2. Is there any simultaneous significant influence of pre-provision operating profit, non-performing loan, return on total assets, dividend yield and firm size towards price to book value in Indonesia Category-IV banks?

3.1.3. Which variable has the most significant influence towards price to book value in Indonesia Category-IV banks?

3.1.4. What is the average technical efficiency of Category-IV banks in Indonesia during 1Q2007 - 4Q2015? 


\subsection{Estimation of the Determinants of Price to Book Value}

The main analysis tool that will be used in this research is statistical tool Eviews (Econometric Views) version 9 and MaxDEA version 6.16. Eviews helps the researcher to make scientific and reliable research (Schwert, 2010). This research uses Eviews to process the raw data statistically in order to get result to be interpreted, such as normality, descriptive, heteroscedasticity, autocorrelation, multicollinearity and multiple regression. Eviews is a helpful statistical tool which provides advanced data analysis, regression and forecasting tools (Schwert, 2010).

This research is using panel data regression analysis, to produce greater degree of freedom and can overcome the problems occurred when there is omitted variables (Widarjono, 2007). There are three alternative estimation models, which are: 1) Common Constant Model, 2) Fixed Effect Model, and 3) Random Effect Model. To decide one, Chow and Hausman test is run, and since the cross section units in this research are less than the independent variables, Hausman test is ignored and Fixed Effect Model is deliberately chosen.

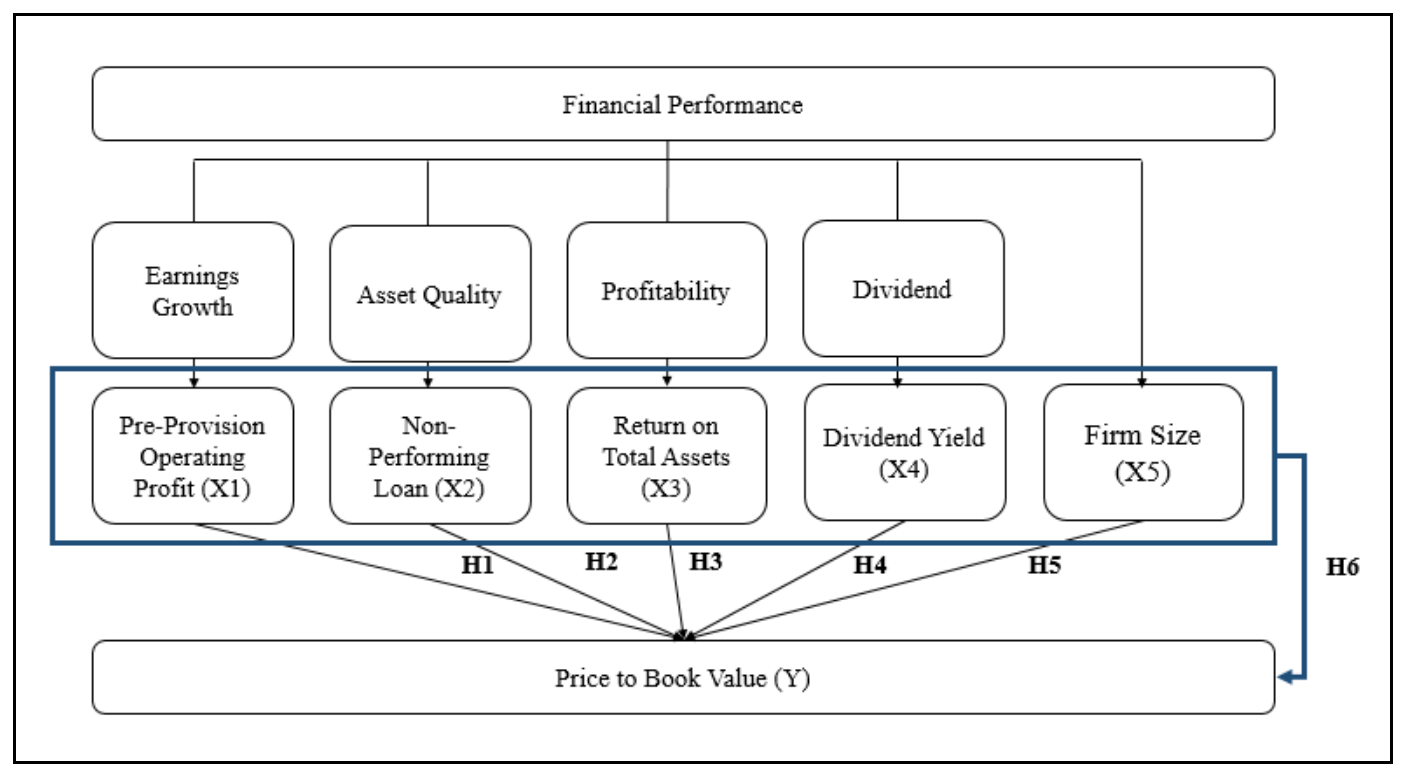

Figure 3.1 Research Theoretical Framework PBV Value Relevance Source: Adjusted by Researcher, 2016

Inside this research, the variables are divided into two types based on its relationship, which are the dependent variable represented by price to book value (Y) and the independent variables represented by pre-provision operating profit $\left(\mathrm{X}_{1}\right)$, non-performing loan $\left(\mathrm{X}_{2}\right)$, return on total assets $\left(\mathrm{X}_{3}\right)$, dividend yield $\left(\mathrm{X}_{4}\right)$, and firm size $\left(\mathrm{X}_{5}\right)$. The researcher aims to see any partial influence from each independent variables towards dependent variable, expressed by $\mathrm{H}_{1}-\mathrm{H}_{5}$ in the black line. Accordingly, the simultaneous influence from all independent variables is expressed by $\mathrm{H}_{6}$ in the blue line. Under multiple regression analysis, $t$-test is conducted to investigate the partial influence of each independent variable by measuring its value of significance. Whilst, F-test is applied to check the simultaneous influence towards the dependent variable.

\subsection{Estimation of Technical Efficiency}


MaxDEA program is used to examine technical efficiency of Category-IV banks in this research. MaxDEA is scientific and powerful software for Data Envelopment Analysis. Based on Kuhail (2013), MaxDEA has many features such as:

- Contained comprehensive DEA models and their possible combinations.

- There is no limitation to DMUs (Decision Making Unit) and variable numbers.

- User-friendly interface

- Standardized databased format.

The researcher decides to use MaxDEA program as the stastical tool to analyze technical efficiency due to the complete features and the unlimited DMUs.

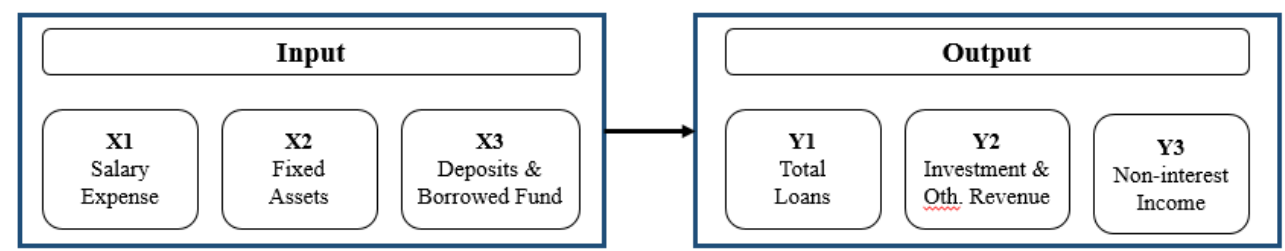

Figure 3.2 Research Theoretical Framework Technical Efficiency

Source: Adjusted by Researcher, 2016

This research uses input and output variables based on intermediation approach. The intermediation approach assumes that financial firms act as an intermediary between savers and borrowers. In past studies, in order to calculate technical efficiency through Data Envelopment Analysis (DEA), the needed variables are input and output. Output and input variables are measured in billions of Rupiah (IDR). The researcher models Indonesian Category-IV banks as multi-product firm producing three outputs by employing three inputs. Those three inputs are salary expense $\left(\mathrm{X}_{1}\right)$, total fixed assets $\left(\mathrm{X}_{2}\right)$ and total deposits \& borrowed funds $\left(\mathrm{X}_{3}\right)$. Whilst, the three outputs are total loans $\left(\mathrm{Y}_{1}\right)$, investment \& other revenue $\left(\mathrm{Y}_{2}\right)$, and non-interest income $\left(\mathrm{Y}_{3}\right)$. Previous bank technical efficiency studies that adopted this approach includes Suzuki \& Sastrosuwito (2011).

\section{Result and Discussion}

\subsection{Determinants of Price to Book Value}

In order to determine the value relevance of price to book value, the selected independent variables are cooked in Eviews 9 under Fixed Effect Model. Below is the result of panel data regression analysis:

Based on Appendix A of multiple regression analysis result, it can be concluded as follows.

1. Pre-provision operating profit has probability value less than $0.05(0.002150<0.05)$ and coefficient regression of 1.481896 , which means pre-provision operating profit has significant and positive influence towards price to book value. This is in line with the theory, in which Lee \& Park (2013) believe that PPOP is better in explaining the profitability of bank compared to ROE ratio.

2. Non-performing loan has probability value less than $0.05(0.002100<0.05)$ and coefficient regression of -0.063118 , which means non-performing loan has significant and negative influence towards price to book value. This is in line with the theory in which Lee \& Park (2013) states that the lower NPL contributes to better asset quality. 
3. Return on total assets has probability value less than $0.05(0.003486<0.05)$ and coefficient regression of 13.6471, which means return on total assets has significant and positive influence towards price to book value. This is in line with the theory, in which Marangu \& Jagongo (2014) proved that the higher return on total assets, implying better managed assets deserve to be valued at a higher price to book value.

4. Dividend yield has probability value less than $0.05(0.000000<0.05)$ and coefficient regression of -0.230905 , which means dividend yield has significant influence towards price to book value. This is in line with the theory stated by Marangu \& Jagongo (2014) in which higher dividend yield implies higher portion of dividend get over the current stock price paid.

5. Firm size has probability value more than $0.05(0.120900>0.05)$ and coefficient regression of -0.418743 , which means firm size has no significant influence towards price to book value. This is contradictive with the theory explained by Hidayah (2014) that explains the positive and significant influence of firm size towards price to book value. Withal, the researcher argues this result to be relevant due to the sample of analysis (4 Category-IV banks) stand in same level of size.

This test gives influences towards the regression model by eliminating variable that has no significant influence towards the price to book value. Since all the independent variables are significant towards price to book value, except the firm size which then be eliminated from the equation. The multiple regression equation is re-written as follows.

$$
\begin{gathered}
Y=13.174370+1.481896 X_{1}-0.063118 X_{2}+13.647100 X_{3}-0.230905 X_{4}- \\
0.418743 X_{5}
\end{gathered}
$$

As shown in Appendix A, F-test result told that pre-provision operating profit, nonperforming loan, return on total assets, firm size and dividend yield are able to explain the variation of price to book value by $82.299 \%$ while the rest of $17.701 \%$ is influenced by other variables which are not examined in this study.

\subsection{Technical Efficiency}

The average technical efficiency for all banks as shown in Appendix B is $96.99 \%$, implying a room of $3.01 \%$ of improvement to reach the full efficiency. Amongst the result, each bank has ever experienced being the most efficient in the research period. As shown in Appendix B, BMRI succeeded to be the most efficient with average technical efficiency score of $98.95 \%$, followed by BBRI with $98.02 \%$, BBNI with $96.04 \%$ and BBCA with $94.94 \%$.

\section{Conclusion and Recommendations}

The independent variables are being sorted based on its level of significance to dependent variable, ROTA influences the dependent variable the most with coefficient of 13.647100, followed by PPOP with 1.481896, dividend yield with -0.240905 and NPL with -0.063118. That said, ROTA influences PBV the most explained partially by signaling theory, in which the management tries to attract investors to buy its stock by publishing a great financial statement result. Bank with high profitability is able to generate high profits, and so be positive vibe for investors to invest in the respective stock. Whilst the firm size has no significance because the unit analysis within this research are in the similar size range. 
The average Category-IV banks technical efficiency period 1Q07 - 4Q15 is equal to 96.99\%. It indicates that Category-IV banks have not been efficient enough and averagely used only $96.99 \%$ of inputs to achieve the maximum outputs. Over the research period, BMRI has better technical efficiency compared to its peers in Category-IV banks in Indonesia. State-owned banks tend to perform better, compared to private-owned, due to its less exposure to global economic phenomena.

After in-depth study and analysis of the research findings, the researcher would like to suggest several points related to the respective parties, which are elaborated as follows:

\section{a. Category-IV Banks}

1) The respective banks in Category-IV are suggested to fully concern and to improve the performance of pre-provision operating growth, non-performing loan, return on total assets and dividend yield, for them to have a higher price to book value, as the aforementioned variables are simultaneously explaining the variation of price to book value by $82.299 \%$.

2) Due to the occurred inefficiency, the respective banks in Category-IV can evaluate their resource management, by concerning in particular factors of influence, such as input variables: salary expense, fixed assets, and deposits \& borrowed funds; and output variables: loans, investment \& other revenue, and non-interest income.

3) So that they can improve the price to book value and technical efficiency score reflecting to the aforesaid variables, the Category-IV banks in Indonesia Stock Exchange can increase its price to book value, which eventually affect its shareholder's equity post.

\section{b. Investment Community}

To have a low price to book value banking stock can tell investors two things: 1) the bank is undervalued, or 2) the bank's fundamental is poor so that it is valued at low price to book value. The condition can do either way or not both. Therefore, it comes into very important knowledge for investors to know the value relevance of price to book, and be able to analyze the fundamental by themselves. This research aims to give better understanding for investment community, to make better investment decision.

\section{c. Future Researchers}

To extend this research, the future researchers are suggested to: 1) add Category-III banks as unit analysis, 2) add more independent variables especially the non-financial factors, and 3) adjust the length of research horizon. By doing so, the future researchers are expected to get bigger picture in determining banking valuation and performance in Indonesia. 
Proceedings of $12^{\text {th }}$ Asia-Pacific Business Research Conference 27 - 28 February, 2017, Concorde Hotel, Kuala Lumpur, Malaysia

ISBN: 978-1-925488-29-6

\section{APPENDIX}

Appendix A. Multiple Regression Analysis Result

Sample: 2007Q1 2015Q4

Periods included: 36

Cross-sections included: 4

Total panel (balanced) observations: 144

White cross-section standard errors \& covariance (d.f. corrected)

\begin{tabular}{|c|c|c|c|c|}
\hline Variable & Coefficient & Std. Error & $\mathrm{t}$-Statistic & Prob. \\
\hline $\mathrm{C}$ & 13.174370 & 4.553029 & 2.893539 & 0.004400 \\
\hline PPOP_X1 & 1.481896 & 0.383046 & 1.258062 & 0.002105 \\
\hline NPL_X2 & -0.063118 & 0.027270 & -2.314565 & 0.002100 \\
\hline ROTA_X3 & 13.647100 & 12.544630 & 1.087884 & 0.003486 \\
\hline SIZE_X4 & -0.418743 & 0.268287 & -1.560803 & 0.120900 \\
\hline DIV_YIELD_X5 & -0.240905 & 0.025983 & -9.271635 & 0.000000 \\
\hline \multicolumn{5}{|c|}{ Effects Specification } \\
\hline \multicolumn{5}{|c|}{ Cross-section fixed (dummy variables) } \\
\hline R-squared & 0.832897 & \multicolumn{2}{|c|}{ Mean dependent var } & 2.865351 \\
\hline Adjusted R-squared & 0.822995 & \multicolumn{2}{|c|}{ S.D. dependent var } & 1.028930 \\
\hline S.E. of regression & 0.432891 & \multicolumn{2}{|c|}{ Akaike info criterion } & 1.223801 \\
\hline Sum squared resid & 25.298300 & \multicolumn{2}{|c|}{ Schwarz criterion } & 1.409414 \\
\hline Log likelihood & -79.113680 & \multicolumn{2}{|c|}{ Hannan-Quinn criter. } & 1.299224 \\
\hline F-statistic & 84.110720 & \multicolumn{2}{|c|}{ Durbin-Watson stat. } & 0.808969 \\
\hline Prob (F-Statistic) & 0.000000 & & & \\
\hline
\end{tabular}

Source: Data processed by Eviews 9

Appendix B. Descriptive Statistics of Quarterly Technical Efficiency Score

\begin{tabular}{|c|c|c|c|c|}
\hline & BBNI & BBCA & BMRI & BBRI \\
\hline 1Q2007 & 0.95171 & 1.00000 & 1.00000 & 0.95349 \\
\hline 2Q2007 & 0.90419 & 0.98340 & 0.96028 & 0.95370 \\
\hline 3Q2007 & 0.95460 & 1.00000 & 0.98318 & 0.94663 \\
\hline 4Q2007 & 0.92072 & 0.99390 & 0.99102 & 0.87711 \\
\hline 1Q2008 & 0.90960 & 1.00000 & 1.00000 & 0.97299 \\
\hline 2Q2008 & 0.90469 & 0.94393 & 0.95974 & 0.94078 \\
\hline 3Q2008 & 0.88792 & 0.91119 & 0.95280 & 0.97862 \\
\hline
\end{tabular}


Proceedings of $12^{\text {th }}$ Asia-Pacific Business Research Conference 27 - 28 February, 2017, Concorde Hotel, Kuala Lumpur, Malaysia ISBN: 978-1-925488-29-6

\begin{tabular}{|c|c|c|c|c|}
\hline $4 Q 2008$ & 0.95032 & 1.00000 & 0.99233 & 0.97643 \\
\hline $1 \mathrm{Q} 2009$ & 0.95984 & 1.00000 & 1.00000 & 0.97685 \\
\hline 2Q2009 & 0.94584 & 1.00000 & 0.98944 & 0.99115 \\
\hline $3 Q 2009$ & 0.96051 & 1.00000 & 0.98767 & 1.00000 \\
\hline $4 Q 2009$ & 0.96803 & 1.00000 & 1.00000 & 1.00000 \\
\hline $1 \mathrm{Q} 2010$ & 0.95174 & 1.00000 & 1.00000 & 1.00000 \\
\hline 2Q2010 & 0.94939 & 1.00000 & 0.97909 & 1.00000 \\
\hline $3 Q 2010$ & 0.94065 & 1.00000 & 0.97195 & 1.00000 \\
\hline 4Q2010 & 0.98983 & 0.96736 & 0.97441 & 1.00000 \\
\hline 1Q2011 & 0.97030 & 0.93765 & 1.00000 & 1.00000 \\
\hline 2Q2011 & 0.95249 & 0.93521 & 1.00000 & 1.00000 \\
\hline 3Q2011 & 0.96516 & 0.93579 & 1.00000 & 0.99932 \\
\hline 4Q2011 & 0.97304 & 0.91842 & 1.00000 & 1.00000 \\
\hline 1Q2012 & 0.96422 & 0.90216 & 0.98661 & 0.98334 \\
\hline 2Q2012 & 0.96033 & 0.90107 & 0.98223 & 0.97657 \\
\hline 3Q2012 & 0.95756 & 0.91074 & 0.98953 & 0.97414 \\
\hline 4Q2012 & 0.96252 & 0.89590 & 0.99085 & 0.94453 \\
\hline $1 \mathrm{Q} 2013$ & 0.96643 & 0.89240 & 1.00000 & 0.99421 \\
\hline 2Q2013 & 0.95593 & 0.89893 & 0.99633 & 0.97737 \\
\hline 3Q2013 & 0.97309 & 0.91177 & 0.98993 & 0.99794 \\
\hline 4Q2013 & 0.99271 & 0.90238 & 1.00000 & 0.98583 \\
\hline $1 \mathrm{Q} 2014$ & 1.00000 & 0.91214 & 1.00000 & 1.00000 \\
\hline 2Q2014 & 0.95922 & 0.91911 & 1.00000 & 1.00000 \\
\hline $3 Q 2014$ & 0.98863 & 0.94059 & 0.98306 & 0.95629 \\
\hline 4Q2014 & 1.00000 & 0.91930 & 0.99630 & 0.99900 \\
\hline 1Q2015 & 0.99658 & 0.92804 & 0.99663 & 1.00000 \\
\hline 2Q2015 & 0.98888 & 0.92765 & 0.99446 & 0.97740 \\
\hline 3Q2015 & 1.00000 & 0.94433 & 0.97629 & 0.96749 \\
\hline 4Q2015 & 1.00000 & 0.94665 & 1.00000 & 0.98837 \\
\hline Average & 0.96046 & 0.94944 & 0.98956 & 0.98026 \\
\hline \multicolumn{5}{|c|}{ Total Average 1Q2007 - 4Q2015 : 0.96993} \\
\hline Max & 1.00000 & 1.00000 & $\mathbf{1 . 0 0 0 0 0}$ & $\mathbf{1 . 0 0 0 0 0}$ \\
\hline Min & 0.88792 & $\mathbf{0 . 8 9 2 4 0}$ & $\mathbf{0 . 9 5 2 8 0}$ & 0.87711 \\
\hline
\end{tabular}

Source: Adjusted by Researcher with MaxDEA 6.16 


\section{REFERENCES}

Alber N. (2015). Determinants of Banking Efficiency: Evidence from Egypt. International Business Research; Vol. 8, No. 8; 2015 ISSN 1913-9004 E-ISSN 1913-9012.

Bader, M. K., Mohamad, S., Ariff, M., \& Hassan, T. (2008). Cost, Revenue, and Profit Efficiency of Islamic Versus Conventional Banks: International Evidence Using Data Envelopment Analysis. Islamic Economic Studies Vol. 15, No. 2, 34.

Berg, B. (2007). Qualitative Research Methods for the Social Sciences (6th ed). Boston: Pearson Education.

Berger, A. N., De Young, R. (1997). "Problem Loans and Cost Efficiency in Commercial Banks", Journal of Banking and Finance, Vol. 21; 1-28.

Berger, A.N., D. Humphrey (1997), "Efficiency of Financial Institutions: International Survey and Directions for Future Research", European Journal of Operational Research, 98, pp. 175-212.

Berger, A. N., W. C. Hunter and S. G.. Timme (1993), "The Efficiency of Financial Institutions: A Review and Preview of Research Past, Present and Future", Journal of Banking and Finance, 17, 221249.

Budi, E. S., \& Rachmawati, E. N. (2014). Analisis Pengaruh Return on Equity, Debt to Equity Ratio, Growth, dan Firm Size Terhadap Price to Book Value pada Perusahaan Property dan Real Estate di Bursa Efek Indonesia. Jurnal Ekonomi, Manajemen dan Akutansi I, 22, 41-60.

Chan, S.G. (2011). Technical Efficiency of Commercial Banks in China: Decomposition into Pure Technical and Scale Efficiency. International Journal of China Studies, 2(1): 2738

Charnes A, Cooper W.W, Rhoads E. (1978). Measuring the Efficiency of Decision Making Units. European Journal of Operational Research; 2; 429-444.

Claessens S. and Horen N. (2014). The Impact of the Global Financial Crisis on Banking Globalization. IMF Working Paper WP/14/197.

Damodaran, A. (2002). Valuation Approaches and Metrics: A Survey of the Theory and Evidence. Stern School of Business, November 2002.

Fama, E. F. (1991). Efficient Capital Market: II. The Journal of Finance, Vol. 46, No. 5, pp. $1575-1617$.

Fare, R., S. Grosskopf, and C.A.K. Lovell (1985), The Measurement of Efficiency of Production, Boston: Kluwer Academic Publishers.

Farell, M. J. (1957). The Measurement of Productive Efficiency. Journal of the Royal Statistical Society. Series A (General), Vol. 120, No. 3 (1957), 253-290.

Ghozali, I. (2005). Aplikasi Analisis Multivariate dengan Program SPSS. Semarang: BP UNDIP.

Gibson, C. H. (2011). Financial Statement Analysis. Canada: South-Western, Cengage Learning.

Gujarati, D. N. (2004). Basic Econometrics. USA: McGraw Hill. 
Hadad, M.D., Santoso, W., Mardanugrah, E. \& Ilyas, D. 2003. Analisis Efisiensi Industri Perbankan Indonesia: Penggunaan Metode Non Parametrik Data Envelopment Analys is (DEA). Research Paper No. 7, Bank Indonesia.

Hadad, M.D., Hall, M.J.B., Kenjegalieva, K., Santoso, W., Satria, R. \& Simper, R. 2008. Efficiency in Indonesian Banking: Recent Evidence. Working Paper No.13, Loughborough University.

Havidz, S. A., \& Setiawan, C. (2015). Bank Efficiency and Non-Performing Financing in the Indonesian Islamic Banks. Asia Journal of Economic Modelling, 3 (3), 61-79.

Heinecke, P. (2011). Success Factors of Regional Strategies for Multinational Corporations: Appropriate Degrees of Management Autonomy and Product Adaptation. London: Physica-Verlag.

Hidayah, N. (2014). The Effect of Company Characteristics Toward Firm Value in the Property and Real Estate Company in Indonesia Stock Exchange. International Journal of Business, Economics and Law, 5(1), 1-8.

International Monetary Fund. (2013). Indonesia Selected Issues. IMF Country Report No. 16/82, March 2016.

Jantana, I. (2012). Pengaruh Struktur Modal, Profitabilitas, dan Likuiditas Terhadap Nilai Perusahaan pada Perusahaan Sektor Barang Konsumsi Sub-Sektor Rokok di BEI Tahun 2007-2011. Jurnal Manajemen, Strategi Bisnis, dan Kewirausahaan , 1-30.

Karim, M. Z. A., Chan, S. G., Hassan, S. (2010). Bank Efficiency and Non Performing Loans: Evidence from Malaysia and Singapore. Prague Economic Papers, 118 - 132.

Lee, Park et. al. (2013). What is the Key Driver of Bank Stock Returns?. The Finsia Journal of Applied Finance, Issue 2, 2013.

Mahendra, A. D., Artini, L. G., \& Suarjaya, A. G. (2012). Pengaruh Kinerja Keuangan Terhadap Nilai Perusahaan Pada Perusahaan Manufaktur Di Bursa Efek Indonesia. Jurnal Manajemen, Strategi Bisnis, dan Kewirausahaan, 6, 130-138.

Marangu, K., \& Jagongo, A. (2014). Price to Book Value Ratio and Financial Statement Variables (An Empirical Study of Companies Quoted At Nairobi Securities Exchange, Kenya). Global Journal of Commerce \& Management Perspective, 50-56.

Nasehah, D., \& Widyarti, E. T. (2012). Analisis Pengaruh ROE, DER, DPR, Growth dan Firm Size Terhadap Price to Book Value (Studi Kasus pada Perusahaan Manufaktur yang Listed di BEI Periode Tahun 2007-2010). Diponegoro Journal of Management, $1(1), 1-9$.

Oleg, Deev. (2011). Methods of Bank Valuation: A Critical Overview. Financial Assets and Financing No.3/2011.

Pakpahan, R. (2010). Pengaruh Faktor-Faktor Fundamental Perusahaan Dan Kebijakan Dividen Terhadap Nilai Perusahaan (Studi Kasus Pada Perusahaan Manufaktur Di BEI Tahun 2003-2007). Ekspansi, 2, 211-227.

Rahmawati, R. (2015). Strategi Peningkatan Efisiensi Biaya Pada Bank Umum Syariah Berbasis Stochastic Frontier Approach dan Data Envelopment Analysis. Buletin Ekonomi Moneter dan Perbankan, Volume 17, Nomor 4, April 2015, 458. 
Santoso, S. (2010). Statistik Non Parametrik Konsep dan Aplikasi dengan SPSS. Jakarta: Elex Media Komputindo.

Sarwono, J. (2006). Metode Penelitian Kuantitatif \& Kualitatif. Yogyakarta: Graha Ilmu.

Schwert, G. W. (2010). Eviews7 User's Guide II. US: Quantitative Micro Software

Sekaran, U., \& Bougie, R. (2011). Research Methods for Business. Great Britain: Wiley.

Setiawan, C., \& Bagaskara B. P. (2016). Non-Performing Financing (NPF) and Cost Efficiency of Islamic Banks in Indonesia Period 2012Q1 to 2015Q2. Journal of Emerging Issues in Economics, Finance and Banking, 5 (1).

Setiawan, C., \& Putri, M. E. (2013). Non-Performing Financing and Bank Efficiency of Islamic Banks of Indonesia. Journal of Islamic Finance and Business Research, 2 (1), 58-76.

Soetanto, T.V. \& Ricky. (2011). Technical Efficiency of Indonesia Commercial Banks: An Application of Two-Stage DEA. Jurnal Manajemen dan Kewirausahaan, Vol. 13, No. 2, September 2011: 107-116

Tambunan T. (2010). The Indonesian Experience with Two Big Economic Crises. Modern Economy, 2010, 1, 156-157.

Suzuki, Y. \& Sastrosuwito, S. (2011). Efficiency and Productivity Change of the Indonesian Commercial Banks. International Proceedings of Economics Development and Research, 7:10-14

Thanassoulis, E. (2001), "Introduction to the Theory and Application of Data Envelopment Analysis: A Foundation Text with Integrated Software", USA: Kluwer Academic Publishers.

Usman, M., Wang, Z., Mahmood, F. \& Shahid, H. 2010. Scale Efficiency in Banking Sector of Pakistan. International Journal of Business and Management, 5(4): 104-116.

Utami, SR. (2013). Efficient Market Hypothesis: Evidence from Indonesia Stock Exchange (IDX). Universitas Multimedia Nusantara

Weiss, N. A. (2012). Introductory Statistics. USA: Addison-Wesley.

Weston, J., \& Brigham, E. (2004). Essential of Managerial Finance. USA: The Dryden Press Harcouft Brace College Publishing.

Widarjono, A. (2009). Ekonometrika Pengantar dan Aplikasinya. Yogyakarta: Ekonisia.

Winarno, Wing Wahyu (2011). Analisis Ekonometrika dan Statistika dengan EViews. Yogyakarta: Unit Penerbit dan Percetakan STIM YKPN Yogyakarta.

Wirawati, N. G. (2008). Pengaruh Faktor Fundamental Terhadap Price Book Value Dalam Penilaian Saham di Bursa Efek Jakarta Dalam Kondisi Krisis Moneter. Buletin Studi Ekonomi, 13, 91-102.

Yang, J. \& Tsatsaronis, K. (2012). Bank Stock Returns, Leverage and the Business Cycle. BIS Quarterly Review, March 2012. 